\title{
Article \\ Role of Standards as an Enabler in a Digital Remanufacturing Industry
}

\author{
Praneetha Pratapa ${ }^{1,+}\left(\mathbb{D}\right.$, Ramesh Subramoniam ${ }^{1, *,+}$ and Jighyasu Gaur ${ }^{2,+}(\mathbb{D}$ \\ 1 Naveen Jindal School of Management, The University of Texas, Dallas, Richardson, TX 75080, USA; \\ praneetha.pratapa@utdallas.edu \\ 2 T A Pai Management Institute, Manipal Academy of Higher Education, Manipal 576104, Karnataka, India; \\ jgaur.ibs@gmail.com \\ * Correspondence: ramesh.subramoniam@utdallas.edu \\ + These authors contributed equally to this work.
}

check for updates

Citation: Pratapa, P.; Subramoniam, R.; Gaur, J. Role of Standards as an Enabler in a Digital Remanufacturing Industry. Sustainability 2022, 14, 1643. https://doi.org/10.3390/su14031643 Academic Editors: Jonathan Sze Choong Low, Mark Mennenga and Carlo Brondi

Received: 15 December 2021

Accepted: 28 January 2022

Published: 30 January 2022

Publisher's Note: MDPI stays neutral with regard to jurisdictional claims in published maps and institutional affiliations.

Copyright: () 2022 by the authors Licensee MDPI, Basel, Switzerland. This article is an open access article distributed under the terms and conditions of the Creative Commons Attribution (CC BY) license (https:// creativecommons.org/licenses/by/ $4.0 /)$.

\begin{abstract}
There is plenty of research describing remanufacturing (reman) as the ultimate form of recycling. However, few studies have shown how standards that provide universally accepted definitions and practices can shift towards digitization and how digital technology can act as a catalyst for digital reman. Furthermore, there is no clear direction as to why and how standards and digital technology should work together in reman. Only minimal research (one article from the SCOPUS database) has explored the intersection of these three areas: reman challenges, standards, and digital technology. Many challenges that reman companies face prevent them from successfully transitioning to sustainable production methods. The challenges include high cost of resources, complex parts design, limited core availability, lack of internationally accepted definitions and protocols, poor design of reverse logistics networks, and poor consumer perceptions. On the other hand, digital technology can act as an enabler fueling environmental resilience through innovation. This paper studies how standards can play a role in helping digital technology solve reman challenges, thereby achieving the United Nations Sustainable Development Goal and providing significant opportunities for innovation for small and large enterprises transitioning towards digital reman. The current study is validated by highly experienced reman professionals using the analytical hierarchical process. It is intended to help practitioners assess their organization's current manufacturing practices and improve resource productivity and business growth using the identified standards and technologies. Three-dimensional printing was found to have the most potential in solving reman challenges. Surprisingly, the Internet of Things ranked low despite lacking information on used products or cores being a significant challenge for suppliers.
\end{abstract}

Keywords: standards; remanufacturing; digital; reverse logistics; circular economy; analytical hierarchical process

\section{Introduction}

Responsible production ensures proper and complete use of material, leading to reduced waste. The United Nations Sustainable Development Goals (SDGs) call for "welldesigned national policy frameworks and instruments" to rapidly enable this transition to decrease resource extraction globally [1,2]. Coincidentally, remanufacturing (reman) is the process of re-investing core materials of a used product back into the production of a like-new product. It is an optimal solution for combating drastic resource depletion where consumption exceeds production capacity at the current rate. Reman requires fewer resources (40\% energy, 30\% material, and 50\% cost) compared to the production of a new product [3]. It differs from other recycling procedures because it returns product quality to the original equipment manufacturer's (OEM) performance. It builds a sustainable supply chain, beginning to end, because it leads to lower costs related to energy and resources and is environmentally friendly by design. 
Reman is a central element of the circular economy (CE) model, which is a "restorative, self-generating ecosystem, where outputs of the system (i.e., waste) are recaptured for use as future inputs (i.e., supply) [4]." It is the most effective value-adding choice to waste management practices within CE [5-8]. In CE, reman is a product life extension strategy that recovers the highest possible intrinsic value of the used product and retains it for the most prolonged period [9-11]. Enhancing resource efficiency and reducing environmental impacts are critical benefits achieved through reman and direct reuse of products [12]. The reman industry acts as a critical enabler of the $\mathrm{CE}$ by minimizing the consumption of non-renewable resources and maximizing their circulation [13].

Reman faces many challenges such as complex product design, high cost of resources, lack of standard definition, unfavorable consumer perception, absence of appropriate reverse logistics network and financials, and lack of core availability and information $[4,14-16]$. These challenges prevent this process from significantly impacting sustainability and are addressed with a series of standards and frameworks. These standards make reman feasible for organizations and even advance their green agendas under the UN.

Digital technologies (DT), which include the Internet of Things (IoT), blockchain, artificial intelligence (AI) and others, can help smooth the implementation of reman standards and allow for low-cost operations, price-sensitive markets, and cheap labor costs $[14,17-19]$. The extant literature suggests the use of DT in the reman industry to achieve efficiency [20-22]. However, reman standards in resolving reman challenges are neglected today in research and practice. The lack of reman standards is considered the most crucial barrier in reman [21].

Moreover, reman standards can play a significant role in mapping reman challenges and appropriate DT. When a reman or a related standard is paired with a specific DT, the remanufactured part becomes accurate in design and quality, is consistent every time it is built, confidently inspected, and tested, and is easily maintained and retrieved due to its stored information history [21]. Therefore, there is merit in developing linkages between reman challenges, reman standards, and DT.

This paper presents the intersection of standards and DT that enable remanufacturing processes. This study establishes links between reman challenges, reman standards, and DT. These links help identify the appropriate DT to address a particular reman challenge along with the reman standard. The study is corroborated by highly experienced reman professionals with extensive knowledge of reman processes to explore the validity and feasibility of the identified solutions.

The remainder of the paper is as follows. In Section 2, the authors conduct a relevant literature review on the reman challenges followed by the standards/frameworks assigned to them and the application of digital technologies in the reman industry. Sections 3 and 4 discuss the methodology, and Section 5 discusses the conclusions.

\section{Literature Review}

The study benefits from three streams of literature: reman challenges, reman standards, and applications of DT in reman. A quick keyword search in the SCOPUS database demonstrated exactly how niche the intersection of these three streams of literature is and how it lacks research across more than 18,000 academic journals hosted in the database (Figure 1). Research articles about the following relevant subject areas were filtered: environmental science, material science, computer science, energy, engineering, social science, business management and accounting, material science, decision science, and psychology. While standards and DT are elaborate on individually, their intersection results only in 1081 papers. This number declines dramatically at the union of reman and standards and even further with reman and DT. Only one research paper was found at the intersection of reman challenges, reman standards, and digital technology. It narrowly focuses on cloud computing as a new enabling technology for the waste electrical and electronic equipment (WEEE) industry. In contrast, this paper broadly analyzes a spectrum of DT 
and maps them to corresponding reman challenges while also utilizing standards to bridge existing processes [23]. The extensive gap in research is evident and provides significant opportunities for broad future research in this field.

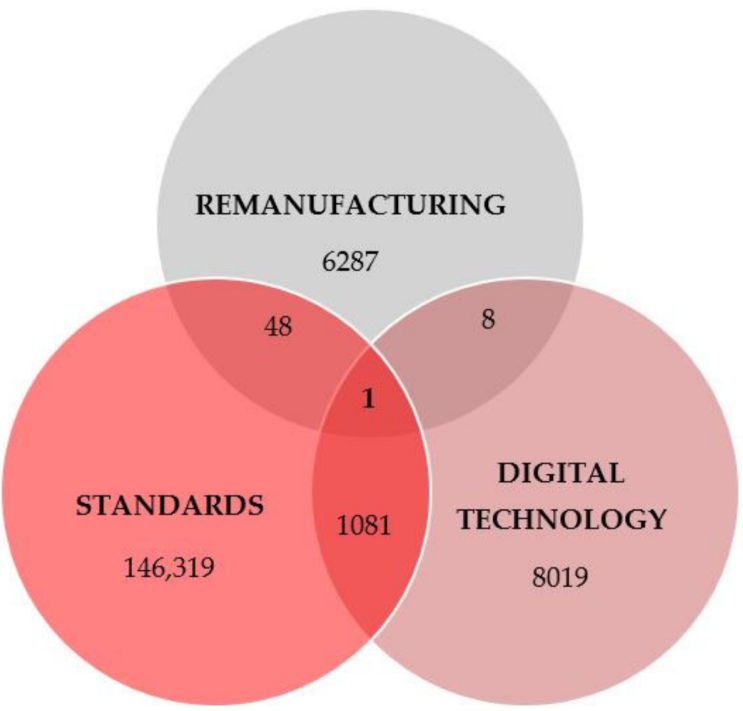

Figure 1. Research publications from SCOPUS on the intersection of remanufacturing, standards and digital technology.

\subsection{Remanufacturing Challenges}

Reman challenges are common across many reman products and operations, involving multiple influencing bodies (i.e., government, consumers) with a broad scope for improvement. The following sections document the research activity.

\subsubsection{Product Design Complexity}

Design patterns are developed from the manufacturing perspective, making production planning and control auditing inherent risks in reusing product parts $[15,24,25]$. In the United States, barriers to reman also lie in the high cost of resources due to limited availability of core parts and issues in product design and quality due to corrosion and assembly misfits. The "Triple Helix Model" proposes a solution derived from the combined efforts from academia, industry, and the government to produce operational solutions, citing lean production strategies catering to process the product and profit improvement [15]. For example, lean production can help lower inventory levels and improve material flow. A reman technology center may be set up at the academic level to work with the neighboring universities and remanufacturers to develop tailored reman technologies. At the policy level, tax structures and regulations could be revised to promote the local manufacturing industry and product recovery activities such as reduce, reuse, and recycle (3R) initiatives and end-of-life (EOL) directives. Automotive reman plants can be piloted with government support. Subsequently, industry-level barriers can be resolved with cooperation among reman stakeholders to enhance the information on material flows and their forecasting and establish state-funded small automotive remanufacturing firms [15]. Standards focusing on efficiently designing product parts and effectively involving multiple bodies of influence in this way are necessary to resolve these concerns.

\subsubsection{Lack of Proper Design of Reverse Logistics and Financials}

Reverse logistics (RL) requires bringing back the used products from the customers and reclaiming their remaining value either by recycling, remanufacturing, or reusing $[26,27]$. However, financial constraints related to initial capital, economic justification, and tax deter proper implementation of RL $[28,29]$. Financial constraint is considered to be the most important strategic factor for reman companies [30]. Furthermore, the lack of knowledge 
about value-added tax, goods, and service tax (GST) can also put a cost burden on companies [31-33]. Countries can reduce these financial constraints by introducing lower taxes for RL activities [34]. On the other hand, companies can reduce uncertainties related to quality, quantity, and acquisition time of used products by proper design of the RL network [35-38]. The Reman Decision Making Framework (RDMF) considers strategic product planning, design for reman, plant location, production systems, physical distribution, and cooperation among reman stakeholders and was developed to assist in decision making for industrial reman processes [30].

\subsubsection{Core Availability and Quality Management}

Reman operations have more significant uncertainty due to limited information regarding the cores' type, quality, and condition, contributing to a greater degree of inspections and core testing to determine suitability. In practice, a product with low reman design capability will make RL an undesirable compulsory issue [39]. The Reman Information Model (RIM) models real-world reman operations considering elements such as the core, the factory, and resources, including work-in-process, and the process describing the interaction of cores. The adaptive remanufacturing simulation algorithm along with RIM would assess the benefits and risks of strategies for production scheduling, planning and other shop floor decisions faced with high levels of uncertainty and complexity [40].

\subsubsection{Lack of Global Acknowledgement}

Regulatory barriers in foreign markets are a prominent hindrance in advancing the reman industry in many countries [16]. For example, customs officials treat core parts as used products and prohibit them from crossing international borders due to confusion and lack of clear distinction between reman products and refurbished products, pre-owned products in existing government policies and regulations. The European Remanufacturing Network (ERN) further verifies that "An absence of an accepted legal definition was found to exacerbate this issue on a global scale [16]." This is due to the lack of universally accepted standards regarding the design, quality, manufacturing, and production of used products. In addition, promoting industrial standards can prevent the unauthorized collection and illegal use of scrap parts, hurting reman reputation and efforts [21,41]. Here, it is evident that sourcing core across borders was heavily limited, and therefore, so is the industry, leading to steep prices and limited availability in local markets. To compete against these challenges, the ERN recommends several solutions revolving around using standards to promote the industry. The solutions include proper labeling of remanufactured products, encouraging public procurement of equipment remanufactured to specified quality standards, creating, and promoting universally developed and accepted standards on reman to raise public awareness, such as PAS 14154 [16].

Furthermore, the reman industry helps contain and circulate advanced critical raw materials such as those with high economic value and supply risk within the economy while also creating high-skill jobs. International Organization for Standardization (ISO) 20245 is a standard that "establishes minimum screening criteria for the cross-border trade of second-hand goods" [42]. However, it does not apply to reman goods. Therefore, there is an immediate urgency to address the import of cores into countries directly. It is pivotal that standards are developed and propagated internationally to provide consistency and transparency within the economy and facilitate the free movement of cores to allow remanufactured products to be more accessible.

\subsubsection{Poor Consumer Perceptions}

Aside from the complexities that nations and industries face in implementing reman procedures, there is significant opposition from consumers who have a negative predisposition towards these products. Products manufactured while being conscious of the environment must also have a robust and attractive market to sell to build and continue production. A study on consumer switching behavior supports the Triple Helix model theory 
proposed earlier and advocates for the support of government policies and corporate influence to educate consumers on the benefits-both internal and environmental-possessed by acquiring remanufactured products [4]. The push-pull-mooring (PPM) theory of migration suggests investigating some push factors such as high prices or poor service that will push consumers away from original products.

On the other hand, pull factors such as superior performance, environmental benefits, and government incentives pull consumers towards alternative solutions that contribute to this shift [4]. Furthermore, it is shown that if a select customer segment is educated about RL activities and their advantages, then the customers will have a positive perception of remanufactured products. For example, Apple, Boeing, and Caterpillar have integrated sustainability-related consumer education activities through remanufacturing [43,44].

There is a crucial distinction created between three segments of consumers within the market structure for reman products: newness-conscious consumers, functionally conscious and environmental conscious segments (FOCs) [45]. However, studies show that newness-conscious consumers would never purchase remanufactured products regardless of lower prices [46]. Therefore, the focus is put on FOCs. A moderate amount of education for a small group of FOC segments has been proven to create a triple-win for the consumers, supply chain, and the environment [47]. It is also interesting that a high number of service failures reported can still ultimately have a positive impact on customer buying patterns, suggesting product popularity [48]. In addition, consumer-generated variables, as opposed to seller-generated variables, were more reliable, trustworthy sources of information for customers [48]. Therefore, organizations should use standards concentrated on consumer education when designing a marketing strategy to increase the customer base of remanufactured products.

The challenges discussed here provide a quick introduction to the problems that are yet to be solved before reman can pick up the pace within manufacturing enterprises or meet the UNs goals for 2030. Coupling technology with standards here provides a unique perspective to solving these challenges. Standards provide consistency in communication and methodology across countries and industries (i.e., automotive, telecommunications). Section 2.2 will discuss the application of standards and DT in a supply chain. Additionally, Table 1 pairs them alongside specific reman challenges they have the potential to solve (Table 1).

Table 1. Remanufacturing challenges, reman standards, and digital technologies as a catalyst for standards implementation.

\begin{tabular}{|c|c|c|}
\hline Reman Challenges & Reman Standards & $\begin{array}{l}\text { Technology as a Catalyst for Standards } \\
\text { Implementation (Examples) }\end{array}$ \\
\hline Product design & $\begin{array}{l}\text { Reman design standards BS } 8887 \text { and BS } 7000 . \\
\text { BS8887: Design for manufacture, assembly, } \\
\text { disassembly and end-of-life processing (MADE) } \\
\text { Part 3: Guide to choosing an appropriate } \\
\text { end-of-life design strategy. ISO 9001:2008 or ISO } \\
\text { 13485:2003 that can evaluate the quality of } \\
\text { recycled parts. }\end{array}$ & $\begin{array}{l}\text { Augmented reality to help to manufacture with } \\
\text { design inputs to support reman; hybrid } \\
\text { manufacturing; laser metal deposition (see high } \\
\text { cost of resources); design for remanufacturing (to } \\
\text { imagine not only how a product will be built, but } \\
\text { how it will be rebuilt). With remanufacturing in } \\
\text { mind, designers may change the materials and } \\
\text { coatings they chose, as well as the accessibility } \\
\text { and layout of parts. }\end{array}$ \\
\hline Core availability & $\begin{array}{l}\text { RIC ANSI standard (RIC001.1-2016) identifies } \\
\text { and inspects "core" material for reusability, } \\
\text { which also includes disassembly and inspection } \\
\text { of parts to ensure conformance to } \\
\text { OEM standards. }\end{array}$ & $\begin{array}{c}\text { Internet of Things (IOT) for product tracking that } \\
\text { helps core availability (also see Lack of } \\
\text { information on usage and repair history). }\end{array}$ \\
\hline
\end{tabular}


Table 1. Cont.

Reman Challenges

Negative perception
of remanufacturing

Skill training, talent
and technology

Lack of information on usage and repair history

High cost of resources
Reman Standards

ISO 14020 details environmental labeling best practices: performance verification through third-party certifications and environmental labels will significantly improve the credibility of remanufacturers and convince the consumer of the recycled product quality. I ISO 9001specifies requirements for a quality management system within an organization that can deliver products that consistently meet customer and regulatory requirements and improve customer satisfaction.

ISO 9001 specifies requirements for a quality management system within an organization that can deliver products that consistently meet customer and regulatory requirements and improve customer satisfaction.

Design-for-remanufacturing frameworks and guidelines (lack of recognized standards for design-for-remanufacturing)
Technology as a Catalyst for Standards Implementation (Examples)
Quality management system to improve customer satisfaction and instill product confidence in the consumer.
EN 45553:2020. This standard will fulfill requirements in the standardization request $\mathrm{M} / 543$ by defining parameters and methods relevant for assessing the ability to repair and reuse products; the ability to upgrade products, excluding remanufacturing; the ability to access or remove certain components, consumables or assemblies from products to facilitate repair, reuse or upgrade and lastly by defining reusability indexes or criteria.

Reman standards require products to reach or exceed original product quality, which means specialist equipment and a skilled labor force is needed. Therefore, there is an increased cost to remanufacture parts, and they are more expensive for consumers than reconditioned/refurbished ones, which do not have to adhere to regulations ensuring such high quality.
Additive manufacturing, augmented reality systems, rapid prototyping, robotic high-pressure cold spray fires tiny particles in a high-pressure air jet, at supersonic speeds at a substrate (allowed the U.S. Air Force to repair sand-pitted helicopters that would have had otherwise been out of service).
Internet of Things (IoT) for data sharing (and, for example, can enable real-time production scheduling for remanufacturing of automobile engines), and monitoring the real-time status of the remanufacturable resources. Blockchain technology provides credibility to product assembly and helps with tracking purposes.
Laser metal deposition (3D printing) uses a laser to melt powder or wire, be it titanium, nickel, cobalt, or a steel alloy, at a focal point into any shape on any surface. It can easily fill in a pitted, grooved, or otherwise worn surface, or entirely coat one, if need be. It allows parts to be fixed that would have previously required too much heat.
Lack of internationally accepted definitions and protocols

RIC001.1-2016 specifically addresses concerns related to a lack of a comprehensive understanding of the remanufacturing industry and thoroughly discusses each sub-process from core acquisition, all the way to product labeling. ISO 20245 is a standard that establishes minimum screening criteria for the cross-border trade of second-hand goods. This standard heavily affects the import of cores into countries.

ISO/TC 323 committee has triggered Reverse logistics network frameworks for circular economy models. EPA pharmaceutical waste management. $\mathrm{n} / \mathrm{a}$

Provide an app for OEMs and independent remanufacturers to find core brokers in their region/location. Make core inventory visible to the customers so that they can buy from wherever it is available. 
Table 1. Cont.

\begin{tabular}{|c|c|c|}
\hline Reman Challenges & Reman Standards & $\begin{array}{l}\text { Technology as a Catalyst for Standards } \\
\text { Implementation (Examples) }\end{array}$ \\
\hline $\begin{array}{l}\text { Reman Business } \\
\text { Case/Financial }\end{array}$ & No known standards. & $\begin{array}{l}\text { Material, labor and overhead costs. Track the } \\
\text { number of returns using IOT and then compute } \\
\text { costs accordingly without duplicating material } \\
\text { costs for multiple returns. }\end{array}$ \\
\hline Core quality management & $\begin{array}{l}\text { Newly published ISO 20245:2017, cross-border } \\
\text { trade of second-hand goods, provides a point of } \\
\text { reference for governments as they intensify their } \\
\text { efforts to establish minimum screening criteria } \\
\text { for the trade of second-hand goods } \\
\text { across borders. }\end{array}$ & $\begin{array}{l}\text { Product tracking using IOT can provide insights } \\
\text { into the conditions the product was exposed or } \\
\text { accidents, for example, before core acceptance. }\end{array}$ \\
\hline $\begin{array}{c}\text { Anticipated } \\
\text { demand forecasting }\end{array}$ & No known standards. & Better reman forecasting models and analytics. \\
\hline $\begin{array}{l}\text { Data integration with } \\
\text { other departments }\end{array}$ & $\begin{array}{c}\text { The ISO } 15926 \text { is a standard for data integration, } \\
\text { sharing, exchange, and hand-over between } \\
\text { computer systems. Having developed a generic } \\
\text { data model and reference data library for process } \\
\text { plants, it turned out that this subject is already so } \\
\text { wide that actually any state information can be } \\
\text { modeled with it. }\end{array}$ & $\begin{array}{l}\text { OEMs focus on forward logistics practices and } \\
\text { aftermarket reman needs to be integrated into } \\
\text { the mainstream planning using integrated ERP } \\
\text { systems and processes. }\end{array}$ \\
\hline
\end{tabular}

\subsection{Remanufacturing Standards}

Several standards can be integrated at different stages of the reman process and positioned to attack a unique reman challenge. These standards can effectively dissolve the existing barriers to reman and enable companies to transition toward implementing digital technologies to improve aftermarket operations, as described below.

\subsubsection{Remanufacturing Process Standard}

The RIC001.1-2016 reman standard developed by the Remanufacturing Industries Council "addresses the specifications and characteristics of the remanufacturing industry and promotes its understanding and credibility" [49]. It aims to resolve the issues caused by a lack of definition and confusion with other processes such as refurbishment and reprocessing that have traditionally prevented reman from gaining momentum. This standard singularly focuses on SDG 12.5, substantially reducing waste generation, and 12.7, promoting sustainable public procurement processes [50]. Figure 2 illustrates a flow map of the reman process according to RIC001.1-2016. It begins with identifying and inspecting "core" material for reusability, including disassembly and inspection of parts, if necessary (Figure 2). Parts of a core that do not meet qualifying criteria will be replaced with new parts to "ensure conformance to original specifications". The core is then used to rebuild the product and is tested for performance before it reenters the supply chain. This way, the nonconforming core is tossed and not reintroduced into the market. For some products, upgrading to the new version will not only extend the remaining life but also improve the performance [51]. This standard recommends that product reman be conducted consistent with recognized quality management systems such as ISO 9001:2008 or ISO 13485:2003 [52]. RIC001.1-2016 addresses concerns related to the lack of a comprehensive understanding of the reman industry and thoroughly discusses each sub-process from core acquisition to product labeling. Few studies have focused on the resource efficiency of reman and direct reuse as its metric, and there are few generally accepted standards and indicators assessing resource efficiency [12]. However, case studies across three industries such as healthcare, wind power, and furniture show a range of potential benefits of reman across triple-bottom-line indicators. The indicators include product life extension, reduced material consumption, product decarbonization, new labor-intensive jobs in-house or into 
the broader business ecosystem, and the use of reman to enhance their market position due to new sales and indirect brand value [53].

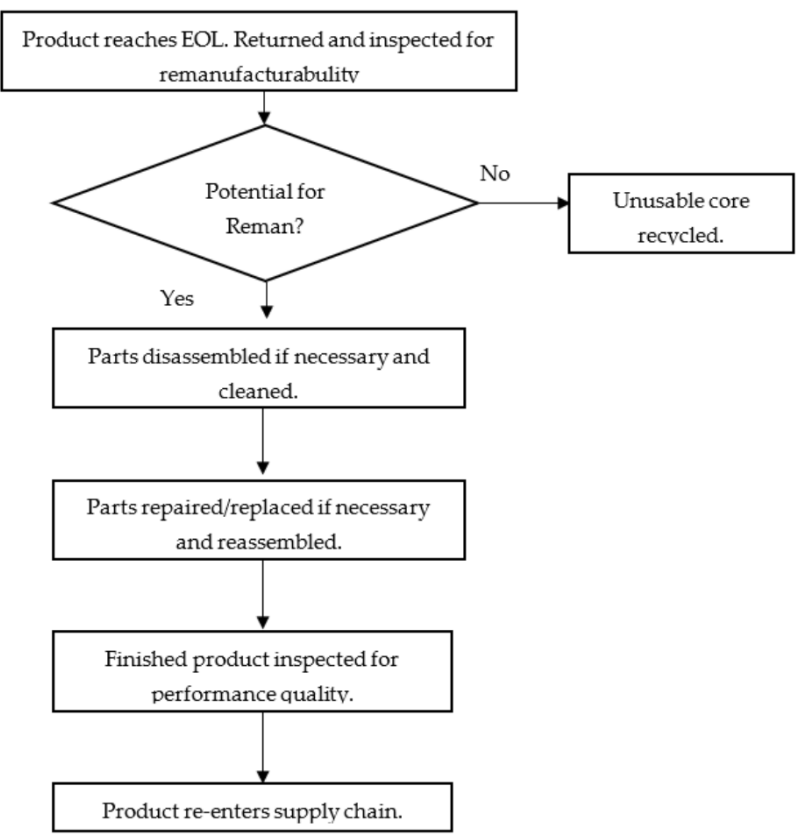

Figure 2. Remanufacturing process.

\subsubsection{Standards throughout the Supply Chain}

The ISO Technical Committee 323 standard holistically examines how CE is measured and assessed for each business. It aims to cover "all aspects of CE including public procurement, production and distribution, end of life as well as wider areas such as a behavioural change in society, and assessment, such as some kind of circularity footprint or index" [54]. ISO 14020 is another standard that details environmental labeling best practices, agreeing with RIC 2016.001 [50]. Both standards agree that performance verification through third-party certifications and environmental labels will significantly improve the credibility of remanufacturers and convince the consumer of recycled product quality. For example, consumers prefer purchasing certified remanufactured auto parts than uncertified ones [55]. Credible quality certifications and favorable online reviews reduce consumers' perceived risks of remanufactured products [56]. It explicitly answers SDG 12.8 on increasing awareness for environmentally friendly products and improving consumer education on why it is essential to advocate for them. ISO 9001 also contributes substantially towards SDG 12 and can further instill product confidence in consumers and positively affect their switching behavior [52]. This standard specifies a quality management system within an organization that can deliver products that consistently meet customer and regulatory requirements and improve customer satisfaction. Lack of standards for EOL products inhibit reman operational efficiency. Additionally, it may result in a lack of communication practices between multidisciplinary product development teams. The challenges related to core and spare part information flow can be fixed by employing established industry standards [57].

\subsubsection{Core Acquisition Framework}

A framework on core acquisition proposed by Gaur et al. (2017) [58] focuses on improving quality product returns, which will result in increased availability of core parts while driving down the cost of resources. The framework also elaborates on consumer disposition behavior and how this piece fits into the forward and reverse supply chain design. Take-back policies, financial incentives, and collaboration with retailers to provide convenient core collection centers are all methods to improve consumer disposition be- 
havior toward remanufactured products and consequently increase core availability [58]. Frameworks can be developed specifically for each industry.

For example, Subramoniam et al. (2009) developed a framework for an automotive aftermarket, which focuses on the circular flow of material. The authors argued that the technological advancement has shortened the automotive product life. Furthermore, the customers demand upgraded versions of the products. Therefore, it is viable to produce remanufactured products with a strong RL network [59].

These standards and frameworks apply to any organization, in any industry, which makes the circular economy such a translatable, versatile, and moldable solution to environmental sustainability. Once standards are implemented, technology can increase process efficiencies. It can be achieved by lowering costs, improving customer experience, relying on fewer resources, and compensating for repairs and losses. In addition, building reliable information highways for complete product life cycles can aid in EOL processing.

\subsection{Applications of Digital Technologies in Remanufacturing}

Several examples of use cases describe how a particular technology can improve specific reman processes such as lot sizing, production scheduling, and parts repairs. In addition, an industry survey was conducted with remanufacturing experts, as described in Section 4, that elaborates further on several technologies capable of aiding reman processes. Some of the top-ranking technologies from the survey are discussed below, along with other mid to low-ranking technologies that are promising and are expected to gain popularity soon to show examples of how the digitization of this industry can be applied to solve common reman challenges [60].

\subsubsection{Three-Dimensional Printing}

Three-dimensional printing technology can assist in the additive reman process for EOL products. Mantelli et al. (2020) elaborate on how low-cost ultraviolet-assisted 3D printing technology can be used to remanufacture glass-fiber-reinforced composites and open possibilities for $\mathrm{CE}$. The reinforced composite waste from various spheres can be used to remanufacture different components [61]. Zheng et al. (2018) developed an algorithm that uses hybrid 3D printing and machining to remanufacture damaged parts [62]. The authors demonstrated an example of repairing a turbine blade virtual model to replace damaged complex parts. The hybrid model combines coordinate measuring machine data collection followed by feeding these data to a computer to reconstruct the 3D model by reverse engineering. Moreover, a computer-aided manufacturing system can generate a tool path for remanufacturing using the virtual simulation of the repair process.

\subsubsection{Blockchain}

Reman process planning is a complex process, and it is difficult for small and midsized remanufacturing enterprises to execute it. Blockchain integrated with case-based reasoning can be used for reman process planning through cross enterprise knowledge sharing [63]. A blockchain search algorithm has been developed to solve the problem of dynamic lot-sizing with product returns suitable for reman [19]. It can be used to determine a production schedule for reman returns so that the demand is satisfied, and total cost is minimized. The planning period is split into a chain of blocks. The solution is derived from finding the shortest path connecting the best combinations of blocks.

\subsubsection{Internet of Things}

The Internet of Things (IoT) is at the forefront of transforming communication between supply chain partners. It allows dynamic management of global network operations [64,65]. Zheng et al. (2018) applied IoT to automobile engines to form the Internet of Manufacturing Things (IoMT) environment, responsible for real-time production scheduling. Using the IoMT environment, identification technology for disassembled engine parts was designed, and real-time management of remanufacturing resources became possible. It resulted in 
the efficient management of resources, cost reduction, and a decrease in energy consumption by $34 \%$, leading to sustainable development and greener production of automobile engines [62]. Almost $46 \%$ of reman products are automotive engines, cylinder blocks, and crankshafts [7]. It provides a considerable opportunity for effective digital reman operations to realize multifold benefits. Joshi and Gupta (2019) examine the possibility of EOL product recovery using IoT [18]. The study proposes the Advanced-Remanufacturing-To-OrderDisassembly-To-Order system, which uses sensors and radio frequency identification tags to evaluate the condition of returned EOL products. It identifies a recovery process such as disassembly, remanufacturing, recycling, or disposal.

\subsubsection{Augmented Reality}

Augmented reality (AR) is a human-computer interaction technology that delivers virtual information in a real-time mode and is also interactive. It was found to improve the efficiency of the disassembly process performed by human operators, thereby optimizing the core-retrieval process for reman $[36,38,66]$. Using AR technology, a process such as a disassembly traditionally considered a non-value-added operation can be optimized to be cost and time-efficient. An evaluation study by Havard et al. (2016) has concluded that AR technology can reduce maintenance time with the improved quality compared to using hardcopy manual or video instructions [67]. Furthermore, Chang et al. (2017) proposed an AR-guided product disassembly framework that conveys disassembly guidance information intuitively to the human operators. Product information is fed into the proposed framework for disassembly planning and content generation, ultimately displayed in an AR interface. Disassembly planning encapsulates information related to the disassembly sequence, and it is enhanced by the visual cues and animations provided by the content generation module. This information is ultimately presented to the end-user in the AR interface [66]. Product disassembly with human operators alone can be prone to errors and time-consuming due to reliance on hardcopy manuals; however, AR can translate the disassembly guidance information properly to human operators responsible for disassembling the products.

\subsubsection{Cloud Computing}

The advantages of cloud computing in reman become especially apparent for WEEE. Cloud-based information systems for service-oriented reman can overcome challenges related to the interrupted exchange of information at the EOL phase and hampers the development of an appropriate and integrated reman environment $[23,68]$. Waiting for information such as delivery and supplier details on incoming core contributes to long lead times, which can cause operations to stop [57]. The loss of product lifecycle information can be attributed to the absence of a methodology or standard that encourages end users to update product status. The cloud can integrate current enterprise remanufacturing capabilities and facilitate a standardized data exchange that maintains knowledge throughout the EEE product lifecycle [23]. It relieves the WEEE collector and remanufacturers from recreating life cycle information via multiple channels and sources. In this way, end-to-end product history is comprehensive and accurately stored on a cloud and overcomes communication bottlenecks across multiple stakeholders and lifecycle phases.

\subsubsection{Industry 4.0 and Artificial Intelligence}

Industry 4.0 has contributed tremendously to the progress of reman facilities and processes. It represents the end-to-end digitization of physical assets and increased analytic capability (artificial intelligence) in a supply chain. It leads to drastic growth of data volume (big data), new patterns of human and machine interaction (augmented reality), and transformation of digital data to physical objects (digital twin) [21]. It creates the opportunity to design intelligent factories for cost-effective and green reman operations by evaluating system health and predicting potential system failures and breakdowns. Using historical and real-time sensor data, remanufacturers can evaluate machine condition via artificial 
intelligence $(\mathrm{AI})$ techniques to increase the prediction accuracy and quality of produced parts. For example, AI can provide real-time visibility into end-to-end planning and vertical integration from sensors through Manufacturing Execution Systems (MES) for faster throughput times and real-time production planning [69]. The captured data about machine activity can additionally be included in EOL product decision making and analyzing the root cause of failure. AI allows manufacturers to embrace sustainable product design and CE. The implementation of AI technologies in CE has increased productivity due to higher optimization and real-time data analysis in manufacturing industries [70]. Furthermore, simulation methods in industrial manufacturing and supply chain management sectors are continuously growing. The emerging need for highly efficient and customizable simulation techniques encourages the expansion of hybrid simulation methods by combining agent-based simulation with artificial intelligence [71].

The present literature review suggests that DT can play a significant role in reducing reman challenges. Reman standards, in our view, can reduce the ambiguity and map DT to the appropriate reman challenges. Furthermore, we want to see which factors organizations give more importance to [72]. Analytical hierarchical process (AHP) is one such technique that can be used to prioritize the factors in consideration [73]. AHP is employed here to analyze how remanufacturers prioritize the use of DT within their organization.

\section{Method-Analytical Hierarchical Process}

The analytic hierarchy process, typically called AHP, is a powerful yet straightforward method and uses experts' pairwise comparisons to make decisions [74]. However, AHP is a subjective process and is very much dependent on the expertise/knowledge of the user. As a result, there can be inconsistencies or poor judgments, and these are measured when using AHP. This paper uses AHP as a tool to assess how remanufacturers are prioritizing the use of digital technologies.

AHP captures strategic goals as weighted criteria that the researcher then uses to rank factors. AHP follows a systematic set of process steps as follows.

1. Construct hierarchies: The problem needs to be decomposed to a hierarchy of criteria to be analyzed independently. Harker et al. outlined the following steps in the process [75].

a. Select a product to reman based on the critical strategic factors (overall goal);

b. If no sub-goal, which is the case here, proceed to the next step;

c. All the digital technologies selected (criteria);

d. All the actors such as the OEM's, OE suppliers, government, core brokers in this reman case (stakeholders);

e. Decision on whether or not to use DT in remanufacturing the product.

2. Establish priorities: In this step, a pairwise comparison of the digital technologies is subjectively performed with the help of the reman experts from the industry [76,77]. First, the experts compare one technology to the other and rank these comparisons. The next step is to check the consistency of these comparisons.

3. Check Consistency: When comparisons are made, it is human to have errors and inconsistencies. The consistency index calculation is used to check whether there was consistency in the input from the experts. The consistency ratio (CR) is used to measure consistency among rankings [78,79]. If the CR value is small, that means there is less deviation and results are consistent [80]. The CR values should be based on several factors, our study considers nine strategic factors. For a detailed explanation of all the steps of the AHP algorithm, please refer to Section 3.4 of Liang et al. (2017) [81].

The survey process and how AHP prioritized the factors are discussed below. 


\section{Industry Survey Development}

\subsection{Expert Panel Selection}

This section focuses on the validation and prioritization of earlier discussed DT from the literature review. For that reason, a small sample size of high-quality is adequate. Based on the guidelines of Silverman (2005), our study used a panel of ten experts for validation and prioritization [82]. The following criteria were used for the selection of experts: (a) He/she should be working in remanufacturing industry; (b) he/she should have a decision-making position in the organization; and (c) he/she should have introduced digital technology in his/her organization. All the ten experts are in decision-making roles in their respective organizations. The experts are from the OE suppliers/distributors and the OEM. The participants were managers or industry executives with reman experience from tier one suppliers and distributors such as ZF, John Deere, Amazon, and OEMs such as Mahindra (India) and Nokia. Furthermore, many members of the remanufacturing standards committee from the RIC participated in the survey. It added validation to the survey because of their exposure to reman standards.

\subsection{AHP Process}

As a first step in the survey process, the survey participants were provided information on current reman challenges based on the authors' industry experience and academic research. In addition, they were also informed about the reman standards available to address these challenges and examples of how DT can be a catalyst for accelerated success implementation (Table 1).

In AHP, two factors or attributes are compared at a time and overall comparisons are performed [83]. Saaty (1980) recommended a 1-9 judgment scale for pairwise comparison, wherein 1 represents equal importance of two attributes considered and 9 indicates the column component has overwhelming supremacy over the row component [74]. Two criteria are evaluated at a time in terms of their relative importance. If criterion $\mathrm{A}$ is exactly as important as criterion $\mathrm{B}$, this pair receives an index of 1 . If $\mathrm{A}$ is much more important than B, the index is 9. All gradations are possible in between. For a "less important" relationship, the fractions $1 / 1$ to $1 / 9$ are available: if $A$ is much less important than $B$, the rating is $1 / 9$. The values are entered row by row into a cross-matrix. The diagonal of the matrix contains only values of 1 . The matrix showing a pairwise comparison of determinants and calculation of the Eigenvector using the normalization approach are shown in Appendices A and B, respectively. The relative weights are used to prioritize the attributes in consideration (refer to Appendix $C$ for calculation).

$$
\mathrm{W}=(0.05,0.15,0.07,0.21,0.03,0.06,0.10,0.26,0.07)
$$

Finally, the calculation of CR is completed. The acceptable value of CR is less than or equal to $10 \%$. However, if the matrix is big then some CR value of up to $20 \%$ is allowed (Gaur et al., 2017) [58]. First, the calculation of consistency index (CI) is needed. CI is calculated as follows:

$$
C I=\frac{\left(\lambda_{\max }-n\right)}{(n-1)}
$$

where $n$ is the number of attributes considered and $\lambda_{\max }$ is calculated by multiplying the column sum row of Appendix B and the Eigenvector matrix w.

$$
\lambda_{\max }=10.19
$$

Computing the consistency index:

$C I=(10.19-9) /(9-1)=0.148$

The calculation of CR required $C I$ to be divided by random inconsistency (RI) value. A random inconsistency table exists in most AHP and ANP reference books. For $n=9$, RI $=1.45$ from Table 2 .

$$
\mathrm{CR}=0.148 / 1.45=0.102
$$


Table 2. Random inconsistency (RI) value for a different number of factors.

\begin{tabular}{ccccccccccccccc}
\hline 1 & 2 & 3 & 4 & 5 & 6 & 7 & 8 & 9 & 10 & 11 & 12 & 13 & 14 & 15 \\
\hline 0 & 0 & 0.58 & 0.9 & 1.12 & 1.24 & 1.32 & 1.41 & 1.45 & 1.49 & 1.51 & 1.54 & 1.56 & 1.57 & 1.59 \\
\hline
\end{tabular}

Since the value of CR (0.102) is close to 0.1 , there is borderline consistency for this application. However, the authors plan to expand the survey to lower the CR value for future work.

A survey questionnaire was used as the next step to focus on: (i) Do you agree with all the reman challenges listed? (ii) Do you agree that all the standards are listed to tackle the reman challenges? (iii) Do you agree that the DT listed will help companies to implement reman standards? The survey participants were provided with a table of the reman challenges, reman standards and the DT that can be a catalyst to implement the standards. These questions helped the authors obtain reman experts' opinions about the reman standards and the industry prioritization of digital technologies to implement these standards.

\section{Survey AHP Results and Discussion}

The survey results and the AHP ranking revealed that the survey participants prioritized 3D printing as the digital technology with the most promise for reman (Table 3).

Table 3. Digital technologies ranked based on AHP analysis.

\begin{tabular}{ccc}
\hline Relative Weight & Digital Technologies & Rank \\
\hline 0.26 & 3D Printing & 1 \\
\hline 0.21 & Inventory and Network Optimization & 2 \\
\hline 0.15 & Prescriptive and Predictive analytics & 3 \\
\hline 0.10 & Artificial Intelligence & 4 \\
\hline 0.07 & Cloud Computing & 5 \\
\hline 0.07 & Augmented Reality & 6 \\
\hline 0.06 & Blockchain & 7 \\
\hline 0.05 & IOT & 8 \\
\hline 0.03 & Autonomous vehicles and drones & 9 \\
\hline
\end{tabular}

This makes sense because many established players in the reman industry, such as Detroit Diesel remanufacturing, have used 3D printing or additive manufacturing for providing spare parts to remanufacture and provide spare parts to the industry. Inventory management is the most challenging problem for the reman industry, and the ability to manage cores (or used parts) makes or breaks a reman program. The use of DT to manage inventory optimization holds a significant promise as remanufacturers battle the increased number of SKUs and thereby look for ways to optimize the inventory. Independent remanufacturers and OEMs have to hold multiple SKUs for older products or risk having no cores for reman if and when there is customer demand. In a recent report, $\mathrm{MHI}$ and Deloitte surveyed more than 1000 supply chain and manufacturing leaders to learn how they are responding to the global pandemic - and how they are transforming their supply chains to become more resilient through the adoption of DT [84].

Consequently, cloud computing, inventory and network optimization, and automation saw the biggest jumps in supply chain investments. Additionally, this report also highlighted the existing gap between forward and RL operations: 3D printing overall was rated a low priority for supply chain company executives. However, it is pivotal that reman executives are heavily involved in discussions related to technology investments so that the aftermarket is considered and reman can be prioritized. Inventory and network 
optimization can lower costs, but 3D printing can boost revenue because it is capable of producing parts at the point of need and shortens lead times for small batches, thereby making on-demand manufacturing a possibility. Currently, RL operations are heavily focused on lowering expenses, but DT such as 3D printing, AI, and cloud computing can be uniquely considered also to increase revenue for reman business operations (Section 2.3.5). The prescriptive and predictive analytics ranked third and tied with inventory optimization and sales and operations planning to forecast and manage products in the reman plant. AI and cloud computing completed the top five technologies that executives prioritized for reman. The use of AI has already penetrated the manufacturing plants in all industries. The use of cloud computing is also spreading rapidly among all manufacturers (mid and large) and industries, evidenced by the growth of cloud computing services such as AWS and Azure [85].

The interesting observation from the survey results was that IoT and drones did not attract that much attention from the reman executives. Core availability remains the major challenge for all remanufacturers, and IoT can greatly benefit tracking cores, thereby resulting in increased availability. Furthermore, a recent post-pandemic IBM report based on a survey of 3000 CEOs from 50 countries and 26 industries identified IoT, cloud computing and $\mathrm{AI}$ as the top technologies that will advance in the next 2-3 years [60]. The authors believe that IoT is currently expanding in the currently manufactured products, and their increased usage in reman will happen when the products become older. Remanufacturers use that to access their location and increase recovery. One of the survey respondents, Chief Engineer for a major automotive OEM, said: "Replacement component availability for the non-OE suppliers is a major issue along with the software available from the OE manufacturer". Another executive, CEO of a major office furniture remanufacturer, continued: "IoT can enable inventory and network optimization using analytics and forecasting for current and emerging challenges and standards". The authors also saw an increased interest from the telecom industry survey participants on the use of IoT for reman compared to other industries.

The participants all agreed that reman technologies identified in Table 1 would help companies implement reman standards to meet the SD 12 goal (Table 1). Furthermore, reman market expansion and technology evolution will further drive the need for standards, which will be met with potential technology mergers and/or acquisitions in the digital ecosystem.

\section{Conclusions and Future Research}

Reman allows for holistic evaluation of an organization's environmentally sustainable practices and thereby converts its supply network into one capable of self-sustaining. Standards are instrumental in this process because they provide unifying measures that guarantee product quality, sustainability, and performance to address the challenges that the remanufacturing industry currently faces. Additionally, implementing the accompanying technologies provide a means to resolve reman challenges that have traditionally prevented enterprises from realizing the circular economy design.

By implementing the standards in conjunction with DT discussed in this paper, an organization can successfully practice responsible production and encourage its consumers and suppliers to play their part in achieving UN SDG 12 by 2030.

This paper discussed the many ways standards coupled with DT could aid in solving common reman challenges across various industries that can enable them to transition towards digital reman. The survey complements the current research and further advocates for the identified DT to be implemented in a hierarchy based on need and feasibility.

The authors believe that there is significant scope for future research, such as adding case studies on companies engaged in deploying DT, how the reman standards enable the reman process and the use of DT to increase productivity and solve the reman challenges listed in this paper. Furthermore, this paper only considered technology for existing products. Future research also has the potential to consider the evolution of product technology such as batteries for electric vehicles that are replacing and will continue to 
replace older product technologies such as internal combustion engine components in the automotive industry.

Author Contributions: Conceptualization, P.P.; Methodology, P.P.; Writing-Original draft, P.P and R.S.; writing—review and editing, P.P., R.S. and J.G.; Supervision, R.S.; Investigation, R.S.; Data Curation, J.G.; Validation, J.G. All authors have read and agreed to the published version of the manuscript.

Funding: This research received no external funding.

Institutional Review Board Statement: Not applicable.

Informed Consent Statement: Not applicable.

Data Availability Statement: Not applicable.

Conflicts of Interest: The authors declare no conflict of interest.

\section{Abbreviations}

$\begin{array}{ll}\text { AI } & \text { artificial intelligence } \\ \text { AHP } & \text { analytical hierarchical process } \\ \text { AWS } & \text { Amazon Web Services } \\ \text { AR } & \text { augmented realty } \\ \text { CE } & \text { circular economy } \\ \text { DT } & \text { digital technology } \\ \text { EOL } & \text { end of life } \\ \text { FOC } & \text { functional and environmental conscious consumer } \\ \text { loT } & \text { Internet of Things } \\ \text { OEM } & \text { original equipment manufacturer } \\ \text { RDMF } & \text { remanufacturing decision-making framework } \\ \text { RL } & \text { reverse logistics } \\ \text { SDG } & \text { sustainable development goal } \\ \text { WEEE } & \text { waste electrical and electronic equipment }\end{array}$

\section{Appendix A}

Table A1. Pairwise comparison average of digital technologies by survey participants.

\begin{tabular}{|c|c|c|c|c|c|c|c|c|c|}
\hline & IOT & PPA & $\begin{array}{c}\text { Cloud } \\
\text { Computing }\end{array}$ & $\begin{array}{c}\text { Inventory } \\
\text { and Network } \\
\text { Optimization }\end{array}$ & $\begin{array}{l}\text { Autonomous } \\
\text { Vehicles } \\
\text { and Drones }\end{array}$ & Blockchain & $\begin{array}{c}\text { Artificial } \\
\text { Intelligence }\end{array}$ & 3D Printing & $\begin{array}{c}\text { Augmented } \\
\text { Reality }\end{array}$ \\
\hline IOT & 1.00 & 0.33 & 0.50 & 0.33 & 4.00 & 0.50 & 0.25 & 0.25 & 0.25 \\
\hline PPA & 3.00 & 1.00 & 3.00 & 0.50 & 4.00 & 3.00 & 3.00 & 0.33 & 4.00 \\
\hline Cloud Computing & 2.00 & 0.33 & 1.00 & 0.25 & 4.00 & 1.00 & 0.33 & 0.33 & 2.00 \\
\hline $\begin{array}{c}\text { Inventory and } \\
\text { Network Optimization }\end{array}$ & 3.00 & 2.00 & 4.00 & 1.00 & 5.00 & 4.00 & 4.00 & 0.50 & 5.00 \\
\hline $\begin{array}{l}\text { Autonomous vehicles } \\
\text { and drones }\end{array}$ & 0.25 & 0.25 & 0.25 & 0.20 & 1.00 & 0.50 & 0.50 & 0.25 & 0.50 \\
\hline Blockchain & 2.00 & 0.33 & 1.00 & 0.25 & 2.00 & 1.00 & 0.50 & 0.25 & 0.50 \\
\hline Artificial Intelligence & 4.00 & 0.33 & 3.00 & 0.25 & 2.00 & 2.00 & 1.00 & 0.25 & 3.00 \\
\hline 3D Printing & 4.00 & 3.00 & 3.00 & 2.00 & 4.00 & 4.00 & 4.00 & 1.00 & 5.00 \\
\hline Augmented Reality & 4.00 & 0.25 & 0.50 & 0.20 & 2.00 & 2.00 & 0.33 & 0.20 & 1.00 \\
\hline SUM & 23.25 & 7.83 & 16.25 & 4.98 & 28.00 & 18.00 & 13.91 & 3.36 & 21.25 \\
\hline
\end{tabular}

\section{Appendix B}

Table A2. Normalized pairwise comparison average of digital technologies by survey participants.

\begin{tabular}{ccccccccc}
\hline & IOT & PPA & $\begin{array}{c}\text { Cloud } \\
\text { Computing }\end{array}$ & $\begin{array}{c}\text { Inventory } \\
\text { and Network } \\
\text { Optimization }\end{array}$ & $\begin{array}{c}\text { Autonomous } \\
\text { Vehicles } \\
\text { and Drones }\end{array}$ & $\begin{array}{c}\text { Blockchain } \\
\text { Antificial } \\
\text { Intelligence }\end{array}$ & $\begin{array}{c}\text { Augmented Printing } \\
\text { Reality }\end{array}$ \\
\hline IOT & 0.04 & 0.04 & 0.03 & 0.07 & 0.14 & 0.03 & 0.02 \\
PPA & 0.13 & 0.13 & 0.18 & 0.10 & 0.14 & 0.17 & 0.07 \\
\hline
\end{tabular}


Table A2. Cont.

\begin{tabular}{|c|c|c|c|c|c|c|c|c|c|}
\hline & IOT & PPA & $\begin{array}{c}\text { Cloud } \\
\text { Computing }\end{array}$ & $\begin{array}{c}\text { Inventory } \\
\text { and Network } \\
\text { Optimization }\end{array}$ & $\begin{array}{l}\text { Autonomous } \\
\text { Vehicles } \\
\text { and Drones }\end{array}$ & Blockchain & $\begin{array}{c}\text { Artificial } \\
\text { Intelligence }\end{array}$ & 3D Printing & $\begin{array}{c}\text { Augmented } \\
\text { Reality }\end{array}$ \\
\hline Cloud Computing & 0.09 & 0.04 & 0.06 & 0.05 & 0.14 & 0.06 & 0.02 & 0.10 & 0.09 \\
\hline $\begin{array}{c}\text { Inventory and } \\
\text { Network Optimization }\end{array}$ & 0.13 & 0.26 & 0.25 & 0.20 & 0.18 & 0.22 & 0.29 & 0.15 & 0.24 \\
\hline $\begin{array}{l}\text { Autonomous vehicles } \\
\text { and drones }\end{array}$ & 0.01 & 0.03 & 0.02 & 0.04 & 0.04 & 0.03 & 0.04 & 0.07 & 0.02 \\
\hline Blockchain & 0.09 & 0.04 & 0.06 & 0.05 & 0.07 & 0.06 & 0.04 & 0.07 & 0.02 \\
\hline Artificial Intelligence & 0.17 & 0.04 & 0.18 & 0.05 & 0.07 & 0.11 & 0.07 & 0.07 & 0.14 \\
\hline 3D Printing & 0.17 & 0.38 & 0.18 & 0.40 & 0.14 & 0.22 & 0.29 & 0.30 & 0.24 \\
\hline Augmented Reality & 0.17 & 0.03 & 0.03 & 0.04 & 0.07 & 0.11 & 0.02 & 0.06 & 0.05 \\
\hline SUM & 1.00 & 1.00 & 1.00 & 1.00 & 1.00 & 1.00 & 1.00 & 1.00 & 1.00 \\
\hline
\end{tabular}

\section{Appendix C}

Relative weight calculation.

$$
\mathrm{w}=1 / 9^{*}\left[\begin{array}{c}
0.04+0.04+0.03+0.07+0.14+0.03+0.02+0.07+0.01 \\
0.13+0.13+0.18+0.10+0.14+0.17+0.22+0.10+0.19 \\
0.09+0.04+0.06+0.05+0.14+0.06+0.02+0.10+0.09 \\
0.13+0.26+0.25+0.20+0.18+0.22+0.29+0.15+0.24 \\
0.01+0.03+0.02+0.04+0.04+0.03+0.04+0.07+0.02 \\
0.09+0.04+0.06+0.05+0.07+0.06+0.04+0.07+0.02 \\
0.17+0.04+0.18+0.05+0.07+0.11+0.07+0.07+0.14 \\
0.17+0.38+0.18+0.40+0.14+0.22+0.29+0.30+0.24 \\
0.17+0.03+0.03+0.04+0.07+0.11+0.02+0.06+0.05
\end{array}\right]=\left[\begin{array}{c}
0.05 \\
0.15 \\
0.07 \\
0.21 \\
0.03 \\
0.06 \\
0.10 \\
0.26 \\
0.07
\end{array}\right]
$$

\section{References}

1. United Nations. Sustainable Consumption and Production. United Nations Sustainable Development. Available online: https:/ / www.un.org/sustainabledevelopment/sustainable-consumption-production/ (accessed on 28 June 2021).

2. United Nations. 70/1. Transforming Our World: The 2030 Agenda for Sustainable Development Preamble. Available online: https:/ / sustainabledevelopment.un.org/post2015/transformingourworld/publication (accessed on 14 July 2021).

3. Chinese Characteristic Remanufacturing Industry and Its Innovation Development. Electric Welding Machine. Available online: https:/ / en.cnki.com.cn/Article_en/CJFDTotal-DHJI201205003.htm (accessed on 14 July 2021).

4. Hazen, B.T.; Mollenkopf, D.A.; Wang, Y. Remanufacturing for the Circular Economy: An Examination of Consumer Switching Behavior. Bus. Strateg. Environ. 2017, 26, 451-464. [CrossRef]

5. Biswas, W.; Rosano, M. A life cycle greenhouse gas assessment of remanufactured refrigeration and air conditioning compressors. Int. J. Sustain. Manuf. 2011, 2, 222-236. [CrossRef]

6. Blomsma, F.; Brennan, G. The Emergence of Circular Economy: A New Framing Around Prolonging Resource Productivity. J. Ind. Ecol. 2017, 21, 603-614. [CrossRef]

7. Govindan, K.; Madan Shankar, K.; Kannan, D. Application of fuzzy analytic network process for barrier evaluation in automotive parts remanufacturing towards cleaner production-A study in an Indian scenario. J. Clean. Prod. 2016, 114, 199-213. [CrossRef]

8. Pallaro, E.; Subramanian, N.; Abdulrahman, M.D.; Liu, C. Sustainable production and consumption in the automotive sector: Integrated review framework and research directions. Sustain. Prod. Consum. 2015, 4, 47-61. [CrossRef]

9. Bakker, C.; Wang, F.; Huisman, J.; Den Hollander, M. Products that go round: Exploring product life extension through design. J. Clean. Prod. 2014, 69, 10-16. [CrossRef]

10. Achterberg, E.; Hinfelaar, J.; Bocken, N. Circular Business Models with the Value Hill; Circle Economy: Utrecht, The Netherlands, 2016. Available online: https://research.tudelft.nl/en/publications/master-circular-business-models-with-the-value-hill (accessed on 28 June 2021).

11. Thierry, M.; Salomon, M.; van Nunen, J.; van Wassenhove, L. Strategic Issues in Product Recovery Management. Calif. Manage. Rev. 1995, 37, 114-135. [CrossRef]

12. Liu, B.; Chen, D.; Zhou, W.; Nasr, N.; Wang, T.; Hu, S.; Zhu, B. The effect of remanufacturing and direct reuse on resource productivity of China's automotive production. J. Clean. Prod. 2018, 194, 309-317. [CrossRef]

13. Ripanti, E.F.; Tjahjono, B. Unveiling the potentials of circular economy values in logistics and supply chain management. Int. J. Logist. Manag. 2019, 30, 723-742. [CrossRef]

14. Chakraborty, K.; Mondal, S.; Mukherjee, K. Critical analysis of enablers and barriers in extension of useful life of automotive products through remanufacturing. J. Clean. Prod. 2019, 227, 1117-1135. [CrossRef]

15. Gunasekara, H.; Gamage, J.; Punchihewa, H. Remanufacture for sustainability: Barriers and solutions to promote automotive remanufacturing. Procedia Manuf. 2020, 43, 606-613. [CrossRef] 
16. Parker, D.; Riley, K.; Robinson, S.; Symington, H.; Tewson, J.; Hollins, O. Remanufacturing Market Study. Available online: https:/ / www.remanufacturing.eu/assets/pdfs/remanufacturing-market-study.pdf (accessed on 13 July 2021).

17. Ghoreishi, M.; Happonen, A. Key enablers for deploying artificial intelligence for circular economy embracing sustainable product design: Three case studies. AIP Conf. Proc. 2020, 2233, 050008.

18. Joshi, A.D.; Gupta, S.M. Evaluation of design alternatives of End-Of-Life products using internet of things. Int. J. Prod. Econ. 2019, 208, 281-293. [CrossRef]

19. Li, X.; Baki, F.; Tian, P.; Chaouch, B.A. A robust block-chain based tabu search algorithm for the dynamic lot sizing problem with product returns and remanufacturing. Omega (United Kingdom) 2014, 42, 75-87. [CrossRef]

20. Kerin, M.; Pham, D.T. Smart remanufacturing: A review and research framework. J. Manuf. Technol. Manag. 2020, 31, 1205-1235. [CrossRef]

21. Yang, S.; Raghavendra, M.R.A.; Kaminski, J.; Pepin, H. Opportunities for industry 4.0 to support remanufacturing. Appl. Sci. 2018, 8. [CrossRef]

22. Yeo, N.C.Y.; Pepin, H.; Yang, S.S. Revolutionizing Technology Adoption for the Remanufacturing Industry. Procedia CIRP 2017, 61, 17-21. [CrossRef]

23. Wang, L.; Wang, X.V.; Gao, L.; Váncza, J. A cloud-based approach for WEEE remanufacturing. CIRP Ann. Manuf. Technol. 2014, 63, 409-412. [CrossRef]

24. Ijomah, W.L.; McMahon, C.A.; Hammond, G.P.; Newman, S.T. Development of design for remanufacturing guidelines to support sustainable manufacturing. Robot. Comput. Integr. Manuf. 2007, 23, 712-719. [CrossRef]

25. Wu, C.H. Product-design and pricing strategies with remanufacturing. Eur. J. Oper. Res. 2012, 222, 204-215. [CrossRef]

26. Govindan, K.; Palaniappan, M.; Zhu, Q.; Kannan, D. Analysis of third party reverse logistics provider using interpretive structural modeling. Int. J. Prod. Econ. 2012, 140, 204-211. [CrossRef]

27. Ilgin, M.A.; Gupta, S.M. Environmentally conscious manufacturing and product recovery (ECMPRO): A review of the state of the art. J. Environ. Manag. 2010, 91, 563-591. [CrossRef] [PubMed]

28. Kapetanopoulou, P.; Tagaras, G. Drivers and obstacles of product recovery activities in the Greek industry. Int. J. Oper. Prod. Manag. 2011, 31, 148-166. [CrossRef]

29. Subramanian, N.; Gunasekaran, A.; Abdulrahman, M.; Liu, C. Factors for implementing end-of-life product reverse logistics in the Chinese manufacturing sector. Int. J. Sustain. Dev. World Ecol. 2014, 21, 235-245. [CrossRef]

30. Subramoniam, R.; Huisingh, D.; Chinnam, R.B.; Subramoniam, S. Remanufacturing Decision-Making Framework (RDMF): Research validation using the analytical hierarchical process. J. Clean. Prod. 2013, 40, 212-220. [CrossRef]

31. Janse, B.; Schuur, P.; De Brito, M.P. A reverse logistics diagnostic tool: The case of the consumer electronics industry. Int. J. Adv. Manuf. Technol. 2010, 47, 495-513. [CrossRef]

32. Starostka-Patyk, M.; Zawada, M.; Pabian, A.; Abed, M. Barriers to reverse logistics implementation in enterprises. In Proceedings of the 2013 International Conference on Advanced Logistics and Transport ICALT, Sousse, Tunisia, 29-31 May 2013 ; pp. 506-511.

33. Sharma, S.K.; Panda, B.N.; Mahapatra, S.S.; Sahu, S. Analysis of Barriers for Reverse Logistics: An Indian Perspective. Int. J. Model. Optim. 2011, 1, 101-106. [CrossRef]

34. Bouzon, M.; Govindan, K.; Rodriguez, C.M.T.; Campos, L.M.S. Identification and analysis of reverse logistics barriers using fuzzy Delphi method and AHP. Resour. Conserv. Recycl. 2016, 108, 182-197. [CrossRef]

35. Srivastava, S.K. Network design for reverse logistics. Omega 2008, 36, 535-548. [CrossRef]

36. Galbreth, M.R.; Blackburn, J.D. Optimal acquisition quantities in remanufacturing with condition uncertainty. Prod. Oper. Manag. 2010, 19, 61-69. [CrossRef]

37. Kim, H.J.; Skerlos, S.; Severengiz, S.; Seliger, G. Characteristics of the automotive remanufacturing enterprise with an economic and environmental evaluation of alternator products. Int. J. Sustain. Manuf. 2009, 1, 437-449. [CrossRef]

38. Mukherjee, K.; Mondal, S. Analysis of issues relating to remanufacturing technology-A case of an Indian company. Technol. Anal. Strateg. Manag. 2009, 21, 639-652. [CrossRef]

39. Govindan, K.; Soleimani, H. A review of reverse logistics and closed-loop supply chains: A Journal of Cleaner Production focus. J. Clean. Prod. 2017, 142, 371-384. [CrossRef]

40. Goodall, P.; Sharpe, R.; West, A. A data-driven simulation to support remanufacturing operations. Comput. Ind. 2019, 105, 48-60. [CrossRef]

41. Xia, X.; Govindan, K.; Zhu, Q. Analyzing internal barriers for automotive parts remanufacturers in China using grey-DEMATEL approach. J. Clean. Prod. 2015, 87, 811-825. [CrossRef]

42. International Organization for Standardization. ISO 20245:2017. Cross-Border Trade of Second-Hand Goods; International Organization for Standardization: Geneva, Switzerland, 2007. Available online: https://www.iso.org/standard/68820.html (accessed on 28 June 2021)

43. Ovchinnikov, A.; Blass, V.; Raz, G. Economic and environmental assessment of remanufacturing strategies for product + service firms. Prod. Oper. Manag. 2014, 23, 744-761. [CrossRef]

44. Rashid, A.; Asif, F.M.A.; Krajnik, P.; Nicolescu, C.M. Resource conservative manufacturing: An essential change in business and technology paradigm for sustainable manufacturing. J. Clean. Prod. 2013, 57, 166-177. [CrossRef]

45. Gaur, J.; Amini, M.; Banerjee, P.; Gupta, R. Drivers of consumer purchase intentions for remanufactured products a study of Indian consumers relocated to the USA. Qual. Mark. Res. 2015, 18, 30-47. [CrossRef] 
46. Abbey, J.D.; Meloy, M.G.; Guide, V.D.R.; Atalay, S. Remanufactured products in closed-loop supply chains for consumer goods. Prod. Oper. Manag. 2015, 24, 488-503. [CrossRef]

47. Zhou, Y.; Xiong, Y.; Jin, M. Less is more: Consumer education in a closed-loop supply chain with remanufacturing. Omega (United Kingdom) 2021, 101, 102259. [CrossRef]

48. Van Nguyen, T.; Zhou, L.; Chong, A.Y.L.; Li, B.; Pu, X. Predicting customer demand for remanufactured products: A data-mining approach. Eur. J. Oper. Res. 2020, 281, 543-558. [CrossRef]

49. RIC001.1-2016; Reman Standard. Remanufacturing Industries Council: West Henrietta, NY, USA, 2016. Available online: https: / / remanstandard.us / (accessed on 13 July 2021).

50. International Organization for Standardization. ISO 14020:2000. Environmental Labels and Declarations-General Principles; International Organization for Standardization: Geneva, Switzerland, 2000. Available online: https://www.iso.org/standard/34 425.html (accessed on 28 June 2021)

51. Zhang, J.H.; Chen, M. Assessing the impact of China's vehicle emission standards on diesel engine remanufacturing. J. Clean. Prod. 2015, 107, 177-184. [CrossRef]

52. International Organization for Standardization. ISO 9001:2015. Quality Management Systems-Requirements; International Organization for Standardization: Geneva, Switzerland, 2015. Available online: https://www.iso.org/standard/62085.html (accessed on 28 June 2021).

53. Jensen, J.P.; Prendeville, S.M.; Bocken, N.M.P.; Peck, D. Creating sustainable value through remanufacturing: Three industry cases. J. Clean. Prod. 2019, 218, 304-314. [CrossRef]

54. International Organization for Standardization. ISO/TC 323. Circular Economy; International Organization for Standardization: Geneva, Switzerland, 2018. Available online: https://www.iso.org/committee/7203984.html (accessed on 28 June 2021).

55. Matsumoto, M.; Chinen, K.; Endo, H. Paving the way for sustainable remanufacturing in Southeast Asia: An analysis of auto parts markets. J. Clean. Prod. 2018, 205, 1029-1041. [CrossRef]

56. Matsumoto, M.; Chinen, K.; Endo, H. Comparison of U.S. and Japanese Consumers' Perceptions of Remanufactured Auto Parts. J. Ind. Ecol. 2017, 21, 966-979. [CrossRef]

57. Kurilova-Palisaitiene, J.; Sundin, E.; Poksinska, B. Remanufacturing challenges and possible lean improvements. J. Clean. Prod. 2018, 172, 3225-3236. [CrossRef]

58. Gaur, J.; Subramoniam, R.; Govindan, K.; Huisingh, D. Closed-loop supply chain management: From conceptual to an action oriented framework on core acquisition. J. Clean. Prod. 2017, 167, 1415-1424. [CrossRef]

59. Subramoniam, R.; Huisingh, D.; Chinnam, R.B. Remanufacturing for the automotive aftermarket-strategic factors: Literature review and future research needs. J. Clean. Prod. 2009, 17, 1163-1174. [CrossRef]

60. IBM. 2021 CEO Study_Find your essential: How to thrive in a post-pandemic reality. Available online: https:/ /www.ibm.com/ thought-leadership/institute-business-value/report/ceo (accessed on 28 June 2021).

61. Mantelli, A.; Levi, M.; Turri, S.; Suriano, R. Remanufacturing of end-of-life glass-fiber reinforced composites via UV-assisted 3D printing. Rapid Prototyp. J. 2020, 26, 981-992. [CrossRef]

62. Zheng, Y.; Qureshi, A.J.; Ahmad, R. Algorithm for remanufacturing of damaged parts with hybrid 3D printing and machining process. Manuf. Lett. 2018, 15, 38-41. [CrossRef]

63. Li, S.; Zhang, H.; Yan, W.; Jiang, Z. A hybrid method of blockchain and case-based reasoning for remanufacturing process planning. J. Intell. Manuf. 2021, 32, 1389-1399. [CrossRef]

64. Verdouw, C.N.; Wolfert, J.; Beulens, A.J.M.; Rialland, A. Virtualization of food supply chains with the internet of things. J. Food Eng. 2016, 176, 128-136. [CrossRef]

65. Bechtsis, D.; Tsolakis, N.; Vlachos, D.; Srai, J.S. Intelligent Autonomous Vehicles in digital supply chains: A framework for integrating innovations towards sustainable value networks. J. Clean. Prod. 2018, 181, 60-71. [CrossRef]

66. Chang, M.M.L.; Ong, S.K.; Nee, A.Y.C. AR-guided Product Disassembly for Maintenance and Remanufacturing. Procedia CIRP 2017, 61, 299-304. [CrossRef]

67. Havard, V.; Baudry, D.; Savatier, X.; Jeanne, B.; Louis, A.; Mazari, B. Augmented industrial maintenance (AIM): A case study for evaluating and comparing with paper and video media supports. In International Conference on Augmented Reality, Virtual Reality and Computer Graphics, Lecture Notes in Computer Science; (including subseries Lecture Notes in Artificial Intelligence and Lecture Notes in Bioinformatics); Springer: Berlin/Heidelberg, Germany, 2016; Volume 9768, pp. 302-320.

68. Wang, X.V.; Wang, L. Digital twin-based WEEE recycling, recovery and remanufacturing in the background of Industry 4.0. Int. J. Prod. Res. 2019, 57, 3892-3902. [CrossRef]

69. PWC. 2016 Global Industry 4.0 Survey What we mean by Industry 4.0. Survey Key Findings. Blueprint for Digital Success. Available online: https://www.pwc.com/gx/en/industries/industries-4.0/landing-page/industry-4.0-building-your-digitalenterprise-april-2016.pdf (accessed on 28 June 2021).

70. Golden, B.L.; Wasil, E.A.; Levy, D.E. Applications of the Analytic Hierarchy Process: A Categorized, Annotated Bibliography. In The Analytic Hierarchy Process; Springer: Berlin/Heidelberg, Germany, 1989; pp. 37-58.

71. Negahban, A.; Smith, J.S. Simulation for manufacturing system design and operation: Literature review and analysis. J. Manuf. Syst. 2014, 33, 241-261. [CrossRef]

72. Kamenetzky, R.D. The Relationship Between The Analytic Hierarchy Process And The Additive Value Function. Decis. Sci. 1982, 13, 702-713. [CrossRef] 
73. Saaty, T.L. Decision Making With The Analytic Hierarchy Process. undefined 2002, 9, 215-229. [CrossRef]

74. Saaty, T.L. The Analytic Hierarchy Process; McGraw Hill: New York, NY, USA, 1980; References-Scientific Research Publishing; Available online: https:/ / www.scirp.org/(S(351jmbntvnsjt1aadkposzje))/reference/ReferencesPapers.aspx?ReferenceID=1977 048 (accessed on 16 August 2021).

75. Harker, P.T.; Vargas, L.G. Theory Of Ratio Scale Estimation: Saaty's Analytic Hierarchy Process. Manag. Sci. 1987, 33, 1383-1403. [CrossRef]

76. Basarir, A.; Gillespie, J.M. Multidimensional goals of beef and dairy producers: An inter-industry comparison. Agric. Econ. 2006, 35, 103-114. [CrossRef]

77. Hefner, R. Book Review: Torgerson, W.S. Theory and Methods of Scaling. New York: John Wiley and Sons, Inc., $1958 ;$ p. 460. Behav. Sci. 1959, 4, 245-247. [CrossRef]

78. Saaty, T.L. How to Make a Decision: The Analytic Hierarchy Process. Interfaces (Providence). 1994, 24, 19-43. [CrossRef]

79. Cheng, E.W.L.; Li, H. Development of a conceptual model of construction partnering. Eng. Constr. Archit. Manag. 2001, 8, 292-303. [CrossRef]

80. Ong, S.K.; Koh, T.H.; Nee, A.Y.C. Assessing the environmental impact of materials processing techniques using an analytical hierarchy process method. J. Mater. Process. Technol. 2001, 113, 424-431. [CrossRef]

81. Liang, H.; Ren, J.; Gao, S.; Dong, L.; Gao, Z. Comparison of Different Multicriteria Decision-Making Methodologies for Sustainability Decision Making. Hydrog. Econ. Supply Chain. Life Cycle Anal. Energy Transit. Sustain. 2017, 189-224. [CrossRef]

82. Silverman, D. Doing Qualitative Research; Sage Publications: Thousand Oaks, CA, USA, 2017; p. 470.

83. Kang, M.; Stam, A. PAHAP: A Pairwise Aggregated Hierarchical Analysis of Ratio-Scale Preferences. Decis. Sci. 1994, 25, 607-624. [CrossRef]

84. 2020 MHI Annual Industry Report_Embracing the Digital Mindset. Available online: https://www.mhi.org/publications/report (accessed on 11 July 2021).

85. Sathish, A.; Dhanabalan, T. Transforming Indian industries through artificial intelligence and robotics in industry 4.0. Int. J. Mech. Eng. Technol. IJMET 2018, 9, 835-845. 